\title{
ANALISIS BEBAN KERJA UNTUK MENENTUKAN JUMLAH OPTIMAL OPERATOR PADA BAGIAN PROSES PABRIK KELAPA SAWIT (Studi Kasus: PT. Sentosa Kalimantan Jaya)
}

\section{WORKLOAD ANALYSIS TO DETERMINE THE OPTIMAL NUMBER OF OPERATORS IN THE PALM OIL MILL PROCESS (Case Study: PT. Sentosa Kalimantan Jaya)}

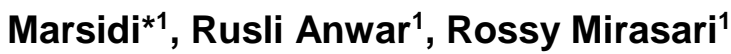 \\ ${ }^{1}$ Politeknik Pertanian Negeri Samarinda, Kampus Gunung Panjang, Jl. Samratulangi, \\ Samarinda, Indonesia \\ marsidi.wa@gmail.com
}

\begin{abstract}
ABSTRAK
This research is motivated by the difficulty in determining the optimal number of human resources required. To be able to calculate HR requirements accurately, a device called a Workload Analysis (ABK) is needed. This study aims to analyze the operator's job description, an overview of the use of operator working time, and workload and needs. The method used is job description analysis, calculation of productive work time usage with work sampling method, and workload analysis using Full Time Equivalent (FTE) method based on work unit activity. The results of the workload analysis show that there are job descriptions that have not been listed in the written description of the company and there are still stations that have a written job description that does not match the work in the field. The percentage of productive working time for operators is between $42 \%$ and $77 \%$, all of which are still low because they are below the standards set by the company, which is $85 \%$. Calculation of the workload of the process part operator, obtained an FTE figure of 7.6 which means the optimal number of operators required by the process section is 8 people. This number is in accordance with the actual number in the process section, namely 8 people.
\end{abstract}

Keywords: Full Time Equivalent (FTE), Workload Analysis, Work Sampling

\section{PENDAHULUAN}

Banyaknya industri minyak kelapa sawit di Indonesia menuntut para produsen CPO untuk mampu bersaing di dalam pangsa pasar. Persaingan industri yang semakin ketat menuntut perusahaan untuk mengoptimalkan seluruh sumber daya yang dimiliki dalam menghasilkan CPO yang berkualitas tinggi. Sumber daya manusia (SDM) merupakan sumber daya utama yang dimiliki perusahaan. Faktor-faktor produksi dalam perusahaan seperti modal, mesin, dan material dapat bermanfaat apabila telah diolah oleh SDM secara maksimal.

Perencanaan kebutuhan sumber daya manusia (SDM) penting untuk diterapkan dalam organisasi dan lembaga baik profit maupun non profit. Salah satu hambatan dalam perencanaan SDM adalah sulitnya menentukan jumlah optimal SDM yang dibutuhkan. Ketersediaan SDM yang berkualitas dengan kuantitas yang tepat menjadi hal yang perlu dikelola seefektif dan seefisien mungkin. Perencanaan SDM menjadi elemen penting dalam mengembangkan strategi organisasi. Untuk dapat melakukan perhitungan kebutuhan SDM dengan tepat, dibutuhkan perangkat yang disebut dengan Analisis Beban Kerja (ABK) (Pranoto-Retnowati, 2019).

Analisis beban kerja adalah metode yang digunakan untuk mengetahui jumlah waktu yang diperlukan karyawan untuk menyelesaikan suatu pekerjaan. Dengan melakukan analisis tersebut diharapkan dapat diketahui jumlah tenaga kerja yang dibutuhkan untuk menyelesaikan sebuah pekerjaan, baik dalam unit kerja, departemen, divisi, maupun perusahaan. Informasi jumlah optimal karyawan tersebut dapat membantu perusahaan 
dalam merancang strategi perencanaan SDM secar efektif dan efisien.

\section{METODOLOGI}

Dalam penelitian ini penulis beban kerja FTE berdasarkan aktivitas unit kerja, hal ini dikarenakan bagian proses terdiri dari bebarapa unit kerja atau stasiun dan aktivitas di masingmasing unit kerja atau stasiun memiliki beragam pekerjaan.

Dalam pengolahan data langkah pertama yang dilakukan yaitu pemeriksaan dokumen job description (deskripsi pekerjaan) operator bagian proses dengan cara validasi dokumen tersebut kepada responden dan mandor proses melalui kuesioner analisis pekerjaan yang didukung dengan teknik wawancara. Pemeriksaan ditinjau dari segi kesesuaian uraian tugas yang ada di dokumen dengan aktivitas riil di lapangan. Kemudian data tersebut diolah dalam software microsoft word 2010 untuk dijadikan referensi dalam memperbaiki deskripsi pekerjaan dan perhitungan beban kerja. Selain kuesioner analisis pekerjaan penulis juga mencantumkan kuesioner analisis beban kerja. Pertanyaan dalam kuesioner analisis beban kerja berkaitan dengan proses kerja, aktivitas pekerjaan di masing-masing stasiun bagian proses, durasi penyelesaian pekerjaan, frekuensi pekerjaan, dan jumlah operator yang mengerjakan setiap pekerjaan.

Langkah kedua yaitu menetapkan waktu kerja, waktu kerja yang dimaksud adalah waktu kerja efektif, artinya waktu kerja yang secara efektif digunakan untuk bekerja. Waktu kerja efektif yang digunakan dalam penelitian ini ialah waktu kerja efektif operator bagian proses PKS PT. SKJ pada tahun 2018.

Tabel 1. Formulir Perhitungan Beban Kerja
Waktu kerja efektif terdiri atas hari kerja efektif dan jam kerja efektif Menteri Ketenagakerjaan (2016).

Hari kerja efektif adalah jumlah hari kerja operator (sesuai checkrol) dikurangi hari libur dibayar (sesuai checkrol) dan hari absensi (sesuai checkrol). Perhitungannya adalah sebagai berikut: Hari Kerja Efektif $=(A-$ $(B+C)$ ) Keterangan : $(A)=$ Jumlah hari kerja operator (sesuai checkrol) dalam setahun; $(B)=$ Jumlah hari libur dibayar (sesuai checkrol) dalam setahun; $(\mathrm{C})=$ Jumlah hari absensi (sesuai checkrol) dalam setahun.

Jam kerja efektif yaitu jumlah jam kerja formal dikurangi dengan waktu kerja yang hilang karena tidak bekerja (allowance). Allowance yang diberikan oleh perusahaan sebesar 1 jam atau 15 $\%$. Kelonggaran diberikan untuk 3 hal, yaitu untuk kebutuhan pribadi, menghilangkan rasa fatigue, dan hambatan-hambatan yang tidak dapat dihindarkan.

Selanjutnya mengelompokan penggunaan waktu kerja operator berdasarkan kegiatan produktif, tidak produktif, dan pribadi, kemudian dihitung jumlahnya sesuai dengan kegiatan masing-masing. Hasil perhitungan ini didapat dari pengamatan langsung penulis dengan menggunakan metode work sampling.

Langkah ketiga yaitu data yang berupa aktivitas pekerjaan, durasi penyelesaian pekerjaan, frekuensi pekerjaan, dan jumlah operator yang mengerjakan setiap pekerjaan di masukan ke dalam formulir analisis beban kerja pada microsoft word 2010 untuk dijadikan referensi dalam perhitungan jumlah beban kerja rill dan jumlah optimal operator yang ideal pada setiap stasiun bagian proses PKS seperti yang terlihat pada Tabel 1 .

\begin{tabular}{|c|c|c|c|c|c|c|}
\hline No & Kegiatan & $\begin{array}{c}\text { Frekuensi } \\
\text { Kerja }\end{array}$ & $\begin{array}{c}\text { Frekuensi } \\
\text { (Tahun) }\end{array}$ & $\begin{array}{l}\text { Durasi } \\
\text { (Menit) }\end{array}$ & $\begin{array}{c}\text { Jumlah SDM } \\
\text { (Orang) }\end{array}$ & $\begin{array}{c}\text { Beban Kerja } \\
\text { (Orang-Menit) }\end{array}$ \\
\hline $\begin{array}{c}1 \\
2 \\
3 \\
\text { Dst }\end{array}$ & & & & & & \\
\hline
\end{tabular}

Sumber: Pranoto-Retnowati (2019) 
Setelah dilakukan rekapitulasi data di lembar formulir analisis beban kerja, langkah berikutnya adalah menganalisis data, yaitu menghitung volume beban kerja per stasiun bagian proses. Perhitungan volume kerja didapat dengan mengalikan frekuensi dengan durasi dan jumlah orang yang mengerjakan. Setelah itu hasil perhitungan setiap kegiatan dijumlahkan. Total dari hasil penjumlahan merupakan volume pekerjaan setiap stasiun bagian proses. Untuk mengubah menjadi jumlah orang didapat melalui perhitungan FTE yang didapat dari volume beban kerja selama satu tahun dibagi dengan waktu kerja efektif selama satu tahun. Perhitungan FTE memberikan hasil berupa jumlah kebutuhan tenaga kerja efektif untuk setiap stasiun bagian pengolahan.

\section{HASIL DAN PEMBAHASAN}

1. Deskripsi Pekerjaan Bagian Proses PKS PT. SKJ

Deskripsi pekerjaan memberikan informasi mengenai aktivitas kerja operator yang dilakukan di setiap stasiun bagian proses PKS. Penyusunan deskripsi pekerjaan dilakukan berdasarkan informasi yang diperoleh melalui data perusahaan, pengamatan langsung, wawancara dengan operator dan pengecekan oleh mandor proses. Aspek yang dianalisa dalam deskripsi pekerjaan meliputi nama jabatan, atasan langsung, tujuan jabatan, tanggung jawab, wewenang dan uraian tugas operator yang diberikan oleh perusahaan.

Tabel 2. Deskripsi Pekerjaan Operator Loading Ramp

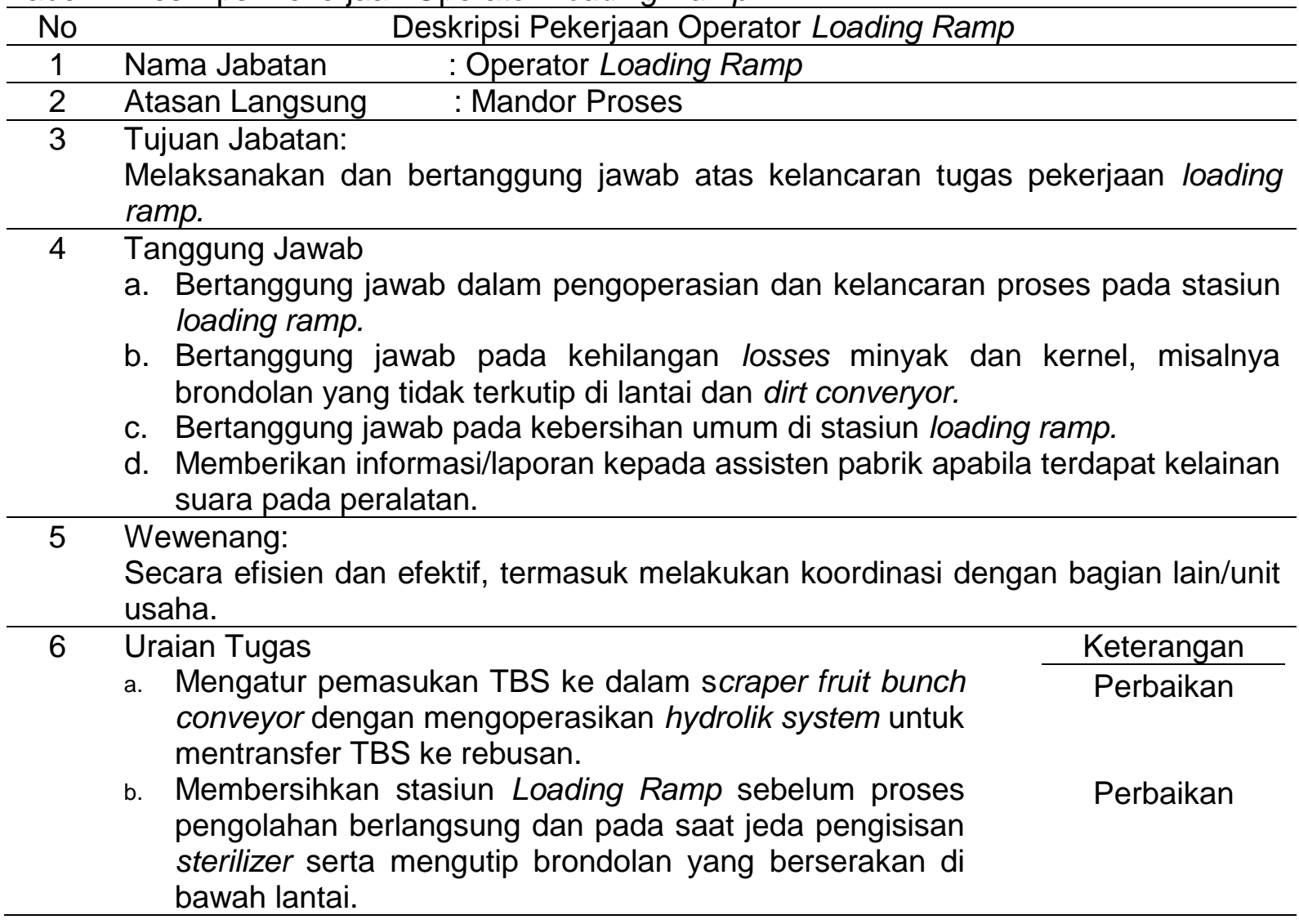

Tabel 3. Deskripsi Pekerjaan Operator Sterilizer

\begin{tabular}{clc}
\hline No & \multicolumn{2}{c}{ Deskripsi Pekerjaan Operator Sterilizer } \\
\hline 1 & Nama Jabatan & : Operator Sterilizer \\
\hline 2 & Atasan Langsung & : Mandor Proses \\
\hline 3 & $\begin{array}{l}\text { Tujuan Jabatan: } \\
\text { Melaksanakan dan }\end{array}$ & bertanggung jawab atas kelancaran tugas pekerjaan \\
\hline
\end{tabular}




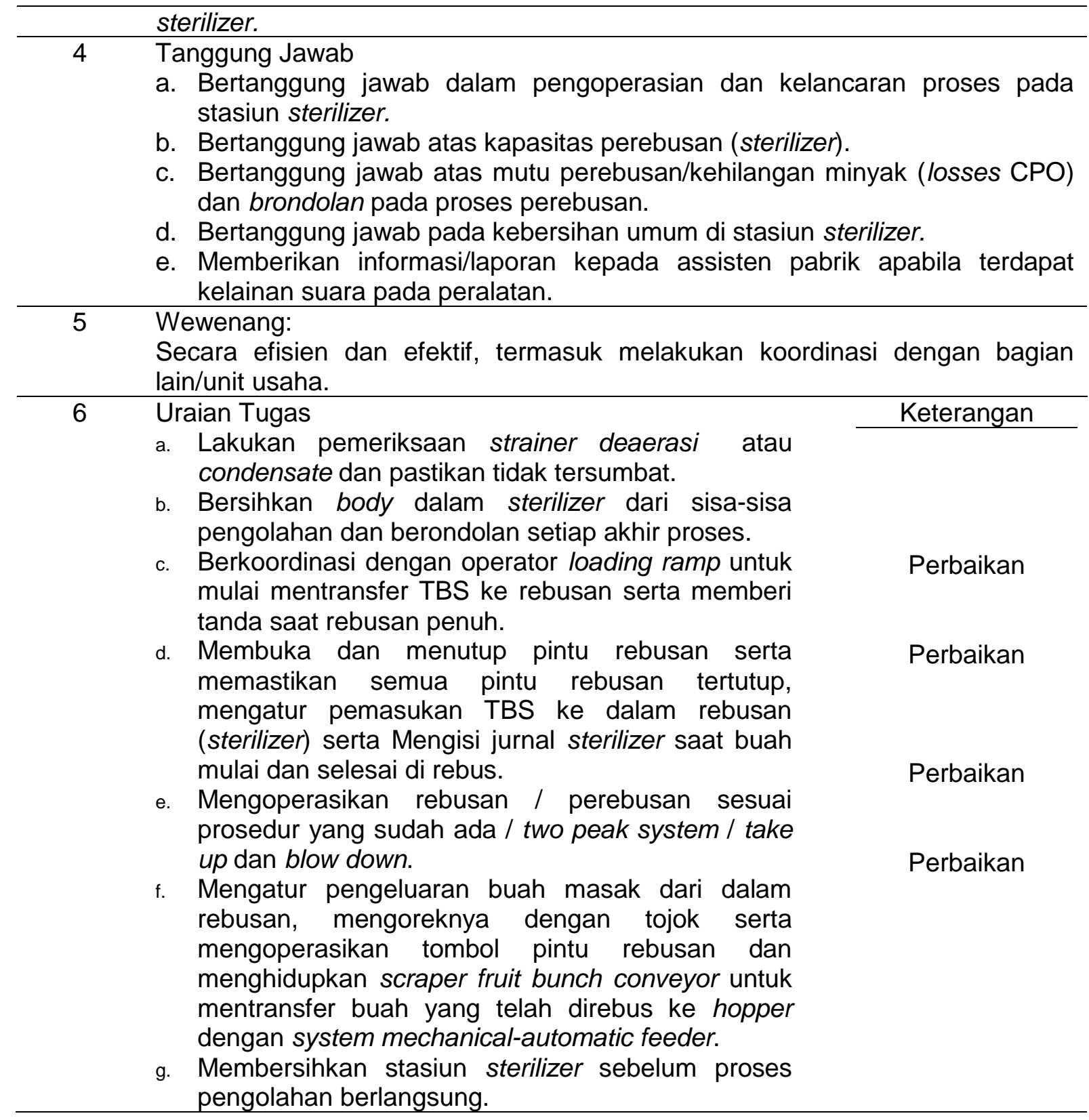

Tabel 4. Deskripsi Pekerjaan Operator Pressing

\begin{tabular}{|c|c|}
\hline No & Deskripsi Pekerjaan Operator Pressing Station \\
\hline 1 & : Operator Pressing Station \\
\hline 2 & Atasan Langsung \\
\hline 3 & $\begin{array}{l}\text { Tujuan Jabatan: } \\
\text { Melaksanakan dan bertanggung jawab atas kelancaran tugas pekerjaan } \\
\text { Pressing Station. }\end{array}$ \\
\hline 4 & $\begin{array}{l}\text { Tanggung Jawab } \\
\text { a. Bertanggung jawab dalam pengoperasian dan kelancaran maupun kapasitas } \\
\text { pres dan digester dalam poses. } \\
\text { b. Bertanggung jawab pada kehilang losses minyak dan losses kernel, } \\
\text { misalnya minyak pada ampas pres dan kernelpada fiber cyclone yang terjadi } \\
\text { akibat presan. } \\
\text { c. Bertanggung jawab pada kebersihan umum di stasiun pressan dan stasiun } \\
\text { digester. } \\
\text { d. Memberikan informasi/laporan kepada assisten pabrik apabila terdapat }\end{array}$ \\
\hline
\end{tabular}




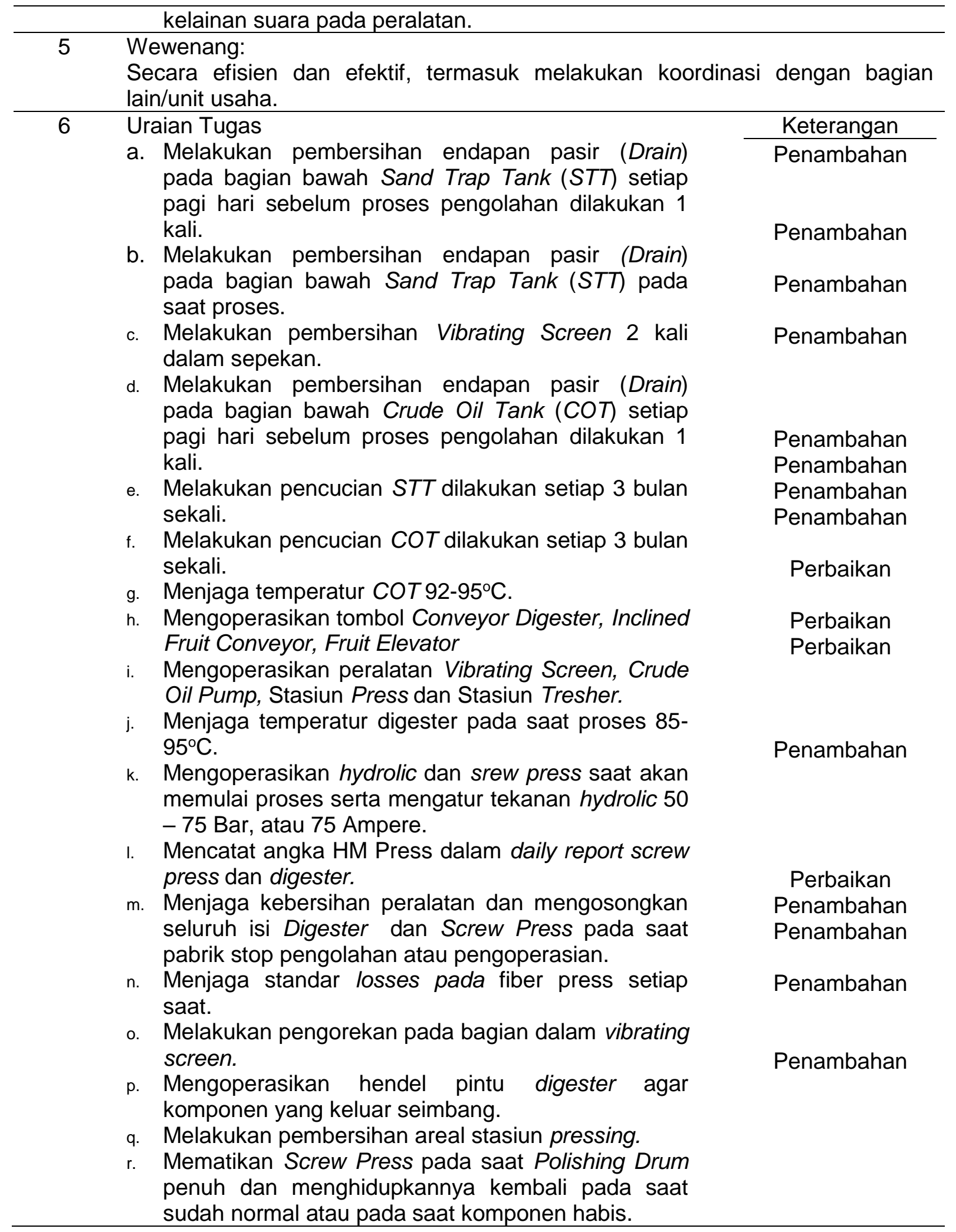

Tabel 5. Deskripsi Pekerjaan Operator Clarification

\begin{tabular}{clll}
\hline No & \multicolumn{4}{c}{ Deskripsi Pekerjaan Operator Clarification Station } \\
\hline 1 & Nama Jabatan & : Operator Clarification Station & \\
\hline 2 & Atasan Langsung & : Mandor Proses & \\
\hline 3 & $\begin{array}{l}\text { Tujuan Jabatan: } \\
\text { Mengatur pelaksanaan }\end{array}$ & serta penanggung jawab operasional Pengolahan \\
\hline
\end{tabular}




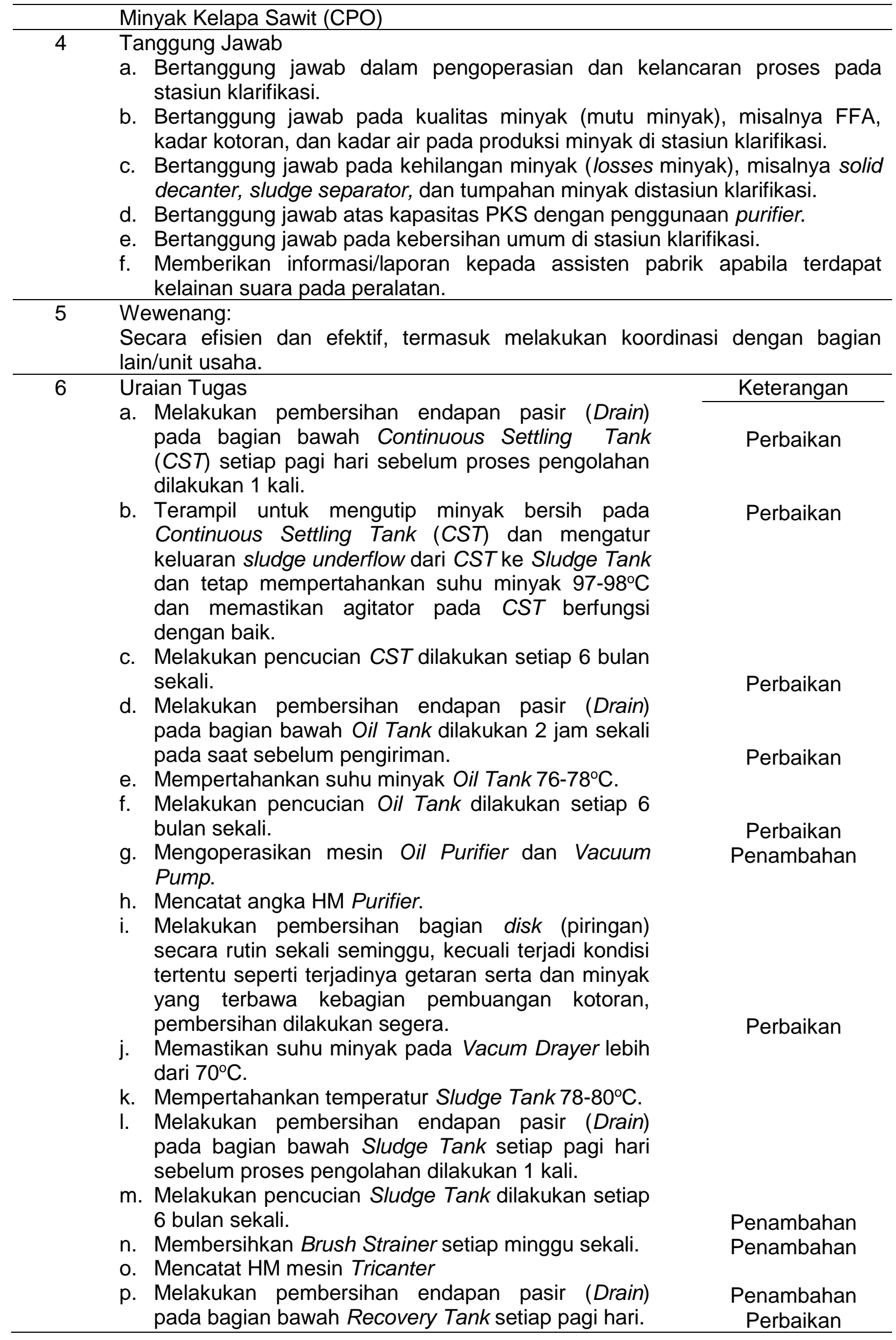


q. Membersihkan Recovery Tank setiap 3 bulan sekali.

r. Terampil untuk mengutip minyak bersih pada Penambahan Recovery Tank dan tetap mempertahankan suhu Penambahan operasi $97-98^{\circ} \mathrm{C}$

s. Memompa grease bering tricanter.

t. Melakukan pembersihan endapan pasir (Drain) Penambahan pada bagian bawah Reclaimed.

u. Membersihkan stasiun klarifikasi sebelum dan pada saat proses pengolahan berlangsung.

Tabel 6. Deskripsi Pekerjaan Operator Nut dan Kernel

\begin{tabular}{|c|c|c|}
\hline No & \multicolumn{2}{|c|}{ Deskripsi Pekerjaan Operator Nut dan Kernel } \\
\hline 1 & Operator Nut dan Kernel & \\
\hline 2 & Atasan Langsung & \\
\hline 3 & $\begin{array}{l}\text { Tujuan Jabatan: } \\
\text { Melaksanakan dan bertanggung jawab atas kelancaran } \mathrm{t} \\
\text { Kernel. }\end{array}$ & kerjaan Nut dan \\
\hline 4 & $\begin{array}{l}\text { Tanggung Jawab } \\
\text { a. Bertanggung jawab dalam pengoperasian dan } \\
\text { stasiun kernel. } \\
\text { b. Bertanggung jawab pada kualitas kernel,misalnya F } \\
\text { kadar air dan kernel pecah pada produksi kernel di st } \\
\text { c. Bertanggung jawab pada kehilang kernel (losses ke } \\
\text { shell, wet shell, fiber cyclone, dan winnowing di stasi } \\
\text { d. Bertanggung jawab pada kebersihan umum di stasiur } \\
\text { e. Memberikan informasi/laporan kepada assisten p } \\
\text { kelainan suara pada peralatan. }\end{array}$ & $\begin{array}{l}\text { an poses pada } \\
\text { lar kotoran, serta } \\
\text { ernel. } \\
\text { lisalnya pada dry } \\
\text { lan kernel. } \\
\text { l. } \\
\text { apabila terdapat }\end{array}$ \\
\hline 5 & $\begin{array}{l}\text { Wewenang: } \\
\text { Secara efisien dan efektif, termasuk melakukan koo } \\
\text { lain/unit usaha. }\end{array}$ & dengan bagian \\
\hline 6 & $\begin{array}{l}\text { Uraian Tugas } \\
\text { a. Mengoperasikan peralatan Kernel Elevator, Kernel } \\
\text { Conveyor, Fuel Conveyor, Air Lock Fiber Cyclone, } \\
\text { Fiber Cyclone Fan, Air Lock Nut Transport } \\
\text { Fan,Hydrocyclone Conveyor,Wet Elevator, Nut } \\
\text { Transport Fan, Polishing Drum, CBC, Cross CBC, } \\
\text { Ripple Mill, Light Tenera Dry Separating, } \\
\text { Hydrocyclone, Claybath. } \\
\text { b. Mengutip stalk di dalam Polishing Drum } \\
\text { mengumpulkannya di dalam artco. } \\
\text { c. Membuang Stalk ke tempat penampungan fiber. } \\
\text { d. Menempatkan artco tepat di bawah Destoner } \\
\text { Separator yaitu lobang untuk keluarnya sampah } \\
\text { batu serta membuangnya jika sudah terkumpul } 1 \\
\text { artco ketempat pembuangan. } \\
\text { e. Mencatat angka HM CBC dan HM Ripple Mill. } \\
\text { f. Membersihkan Vibrator Ripple Mill agar nut yang } \\
\text { keluar seimbang atau lancar. } \\
\text { g. Membersihkan lubang mesh hydrocyclone setiap } \\
\text { saat. } \\
\text { h. Melakukan pembersihan Hydrocyclone pada saat } \\
\text { pabrik stop pengolahan. } \\
\text { i. Melakukan pembersihan silo setiap } 1 \text { tahun sekali. } \\
\text { j. Melakukan pembersihan areal stasiun Nut dan }\end{array}$ & $\begin{array}{l}\text { Penambahan } \\
\text { Penambahan } \\
\text { Penambahan }\end{array}$ \\
\hline
\end{tabular}




\section{Kernel sebelum proses dan setiap akan ganti shift.}

k. Mengatur pintu keluaran Kernel Silo.

Keterangan: Perbaikan=Pembetulan/memperbaiki uraian tugas yang sudah ada di dokumen tertulis, karena tidak sesuai antara dokumen tertulis dengan uraian tugas di lapangan. Sedangkan Penambahan=Memasukan uraian tugas yang ada di lapangan ke dalam dokumen tertulis. Karena ada beberapa uraian tugas yang di jumpai di lapangan tidak tertulis di dokumen job deskripsi.

2. Waktu Kerja Produktif Bagian Proses PKS PT. SKJ

a. Menentukan Waktu Kerja

Produktif

Waktu kerja adalah waktu

yang tersedia dan secara efektif

digunakan oleh operator untuk

bekerja. Penetapan waktu kerja

dilakukan berdasarkan jam kerja operator yang ditetapkan oleh perusahaan selama satu tahun. Berikut merupakan hasil perhitungan waktu kerja efektif bagian pengolahan PKS tahun 2018 dapat dilihat pada Tabel 7.

Tabel 7. Waktu Kerja Efektif Bagian Proses PKS PT. SKJ Tahun 2018

\begin{tabular}{clrl}
\hline No & Perhitungan & Jumlah & Satuan \\
\hline 1 & Jumlah hari tahun 2018 & 365 & Hari \\
4 & Hari libur dibayar (sesuai checkrol) & 70 & Hari \\
5 & Hari absensi (sesuai checkrol & 96 & Hari \\
\hline 6 & Hari kerja efektif tahun 2018 & 199 & Hari \\
7 & Waktu kerja dalam jam & 1.393 & Jam \\
8 & Waktu kerja dalam menit & 83.580 & Menit \\
9 & Evektifitas Kerja & 85 & $\%$ \\
10 & Total jam kerja efektif & 6 & jam/hari \\
& & 360 & menit/hari \\
& & 2.160 & menit/minggu \\
& & 1.194 & Jam/tahun \\
& & 71.640 & menit/tahun \\
\hline
\end{tabular}

b. Perhitungan Waktu Kerja

Produktif

Berikut hasil perhitungan penggunaan waktu kerja produktif operator bagian proses. Work sampling adalah metode yang digunakan peneliti untuk menentuan waktu kerja produktif operator bagian proses PKS dalam penelitian ini, metode ini bertujuan untuk mengetahui berapa presentase waktu produktif dan tidak produktif operator di suatu stasiun kerja. Pengamatan dilakukan selama 7 jam kerja sehari, dan dilaksanakan selama 3 hari untuk satu operator di setiap stasiun.

\section{Berdasarkan}

pengamatan

hasil penggunaan waktu kerja produktif operator bagian proses selama kurang lebih 21 hari kerja menunjukan bahwa presentase waktu kerja produktif operator antara $42 \%$ hingga $77 \%$ semuanya masih tergolong rendah karena dibawah standar yang telah ditentukan perusahaan yaitu sebesar $85 \%$. Hal ini disebabkan karena masih banyak operator yang menggunakan waktu kerja untuk kegiatan tidak produktif seperti, menunda waktu, mengobrol, duduk, bermain gadget yang tidak ada kaitannya dengan pekerjaan. 
Tabel 8. Waktu Kerja Produktif Operator Bagian Proses

\begin{tabular}{clcccc}
\hline No & \multicolumn{1}{c}{ Operator } & $\begin{array}{c}\text { Produktif } \\
\text { (Menit) }\end{array}$ & $\begin{array}{c}\text { Non Produktif } \\
\text { (Menit) }\end{array}$ & $\begin{array}{c}\text { Waktu Kerja } \\
\text { (Menit) }\end{array}$ & $\begin{array}{c}\text { Waktu } \\
\text { Produktif (\%) }\end{array}$ \\
\hline 1 & Loading Ramp & 577 & 683 & 1260 & 46 \\
2 & Sterilizer BA & 808 & 452 & 1260 & 64 \\
3 & Sterilizer BB & 973 & 287 & 1260 & 77 \\
4 & Pressing BA & 578 & 682 & 1260 & 46 \\
5 & Pressing BB & 722 & 538 & 1260 & 57 \\
6 & Clarification & 912 & 348 & 1260 & 72 \\
7 & Nut dan Kernel & 532 & 728 & 1260 & 42 \\
\hline
\end{tabular}

3. Analisis Beban Kerja Bagian Proses PKS PT. SKJ.

Berikut merupakan kesimpulan hasil perhitungan analisis beban kerja FTE berdasarkan aktivitas unit kerja yang dikaitkan dengan kebutuhan operator bagian prose PKS dapat dilihat pada Tabel 9. FTE menunjukan banyak operator yang dibutuhkan dalam suatu stasiun agar dapat bekerja secara optimal serta dapat memberikan rekomendasi bagi perusahaan untuk membandingkan jumlah operator yang ada dengan operator yang dibutuhkan. Berdasarkan hasil pengukuran beban kerja diatas, didapatkan angka FTE sebesar 7.6 yang berati jumlah optimal operator yang dibutuhkan bagian proses PKS yaitu sebanyak 7 orang sedangkan untuk kelebihan FTE sebesar 0.6 dibulatkan menjadi 1 orang pembantu operator (helper) stasiun pressing. Jadi jumlah optimal operator bagian proses adalah sebanyak 7 orang dan 1 orang pembantu operator (helper). Jumlah ini telah sesuai dengan jumlah aktual yang ada di bagian proses yaitu sebanyak 8 orang, yang terdiri dari 1 operator loading ramp, 3 operator sterilizer, 1 operator dan 1 helper pressing, 1 operator clarification, dan 1 operator nut dan kernel.

Tabel 9. Kesimpulan Hasil ABK Bagian Proses PKS

\begin{tabular}{clccccc}
\hline No & Unit Kerja & $\begin{array}{c}\text { Volume } \\
\text { Pekerjaan } \\
\text { (Menit- } \\
\text { Tahun) }\end{array}$ & $\begin{array}{c}\text { Jumlah } \\
\text { SDM Yang } \\
\text { Dibutuhkan } \\
\text { (FTE) }\end{array}$ & $\begin{array}{c}\text { Jumlah } \\
\text { Aktual } \\
\text { SDM }\end{array}$ & $\begin{array}{c}\text { Gap } \\
\text { Jumlah } \\
\text { SDM (FTE) }\end{array}$ & Ket \\
\hline 1 & Loading Ramp & 44.775 & 0.63 & 1 & +0.37 & Underload \\
2 & Sterilizer & 223.328 & 3.12 & 3 & -0.12 & Normal \\
3 & Pressing & 113.105 & 1.58 & 2 & +0.42 & Underload \\
4 & Clarification & 83.415 & 1.16 & 1 & -0.16 & Normal \\
5 & Nut dan Kernel & 79.795 & 1.11 & 1 & -0.11 & Normal \\
\hline
\end{tabular}

Keterangan: Normal (beban kerja sama dengan jumlah pemangku jabatan/operator) nilai FTE 1 sampai dengan 1,28, Underload (beban kerja lebih kecil dibandingkan dengan jumlah pemangku jabatan/opeator) nilai FTE 0 sampai dengan 0,99 , dan Overload (beban kerja lebih besar dibandingkan dengan jumlah pemangku jabatan/operator) nilai FTE berada diatas 1,28.

deskripsi pekerjaan yang belum tercantum di deskripsi tertulis

\section{KESIMPULAN}

Berdasarkan hasil analisis deskripsi pekerjaan, analisis penggunaan waktu kerja, dan beban kerja diatas dapat disimpulkan bahwa:

1. Deskripsi pekerjaan bagian proses PKS telah cukup jelas dibuat oleh perusahaan, akan tetapi masih ada perusahaan serta masih ada stasiun yang memiliki deskripsi pekerjaan tertulis tidak sesuai dengan pekerjaan yang ada di lapangan sehingga dilakukan perbaikan dan penambahan uraian tugas bagian proses.

2. Berdasarkan hasil pengamatan langsung penggunaan waktu kerja 
produktif operator bagian proses selama kurang lebih 21 hari kerja menunjukan bahwa presentase waktu kerja produktif operator antara $42 \%$ hingga $77 \%$ semuanya masih tergolong rendah karena dibawah standar yang telah ditentukan perusahaan yaitu sebesar $85 \%$. Hal ini disebabkan karena masih banyak operator yang menggunakan waktu kerja untuk kegiatan tidak produktif seperti, menunda waktu, mengobrol, duduk, bermain gadget yang tidak ada kaitannya dengan pekerjaan.

3. Berdasarkan hasil perhitungan beban kerja operator bagian proses, didapatkan angka FTE sebesar 7.6 yang berati jumlah optimal operator yang dibutuhkan bagian proses yaitu sebanyak 8 orang. Jumlah ini telah sesuai dengan jumlah aktual yang ada di bagian proses yaitu sebanyak 8 orang, yang terdiri dari 1 operator loading ramp, 3 operator sterilizer, 1 operator dan 1 helper pressing, 1 operator clarification, dan 1 operator nut dan kernel.

\section{DAFTAR PUSTAKA}

Budihardjo M. 2015. Panduan Praktis Penilaian Kinerja Karyawan. Edisi 1. Penebar Swadaya. Jakarta. 172 hal.

Menteri Dalam Negeri. 2008. Peraturan Menteri Dalam Negeri Nomor 12 Tahun 2008 Tentang Pedoman Analisis Beban Kerja di Lingkungan Departemen dalam Negeri dan Pemerintah Daerah. Menteri Dalam Negeri. Jakarta.

Menteri Ketenagakerjaan. 2016. Keputusan Menteri Ketenagakerjaan Republik Indonesia Nomor 128 Tahun 2016 Tentang Pedoman Analisis Beban Kerja di Kementrian
Ketenagakerjaan. Menteri Ketenagakerjaan. Jakarta.

Pardamean M. 2011. Sukses Membuka Kebun dan Pabrik Kelapa Sawit. Edisi 1. Penebar Swadaya. Jakarta.

2014. Mengelola Kebun dan Pabrik Kelapa Sawit Secara Profesional. Edisi 1. Penebar Swadaya. Jakarta. Nomor 198. 2017. Kupas Tuntas Agribisnis Kelapa Sawit Mengelola Kebun dan Pabrik Kelapa Sawit Secara Efektif dan Efisien. Edisi 1. Penebar Swadaya, Jakarta.

Pranoto L.H-Retnowati. 2019. Analisis Beban Kerja Sumber Daya Manusia Perusahaan. Edisi VI. PPM Manajemen, Jakarta. 139 hal.

Ramadhan R. 2014. "Analisis Beban Kerja Dengan Menggunakan Work Sampling dan Nasa-TLX Untuk Menentukan Jumlah Operator". Jurnal Rekayasa dan Manajemen Sistem Industri. Vol. 2, No 5.:964973.

Sekertaris Negara. 2003. Undang-Undang Republik Indonesia Nomor 13 Tahun $2003 \quad$ Tentang Ketenagakerjaan. Lembaran Negara RI Tahun 2003, No. 39. Sekertaris Negara. Jakarta.

Zainal R.I dan Ramadhanti R. 2019. "Need Analysis of Non-Permanent Employees With Full Time Equivalent (FTE) Method". e-Jurnal Apresiasi Ekonomi. Vol. 7, No. 3:119.

Zulpikar-Faozan H. 2009. "Analisis Beban Kerja dan Arah Penataan Organisasi Perangkat Daerah: Studi pada Tiga Satuan Kerja Perangkat Daerah Kabupaten Musi Rawas". Jurnal IImu Administrasi. Vol. 6, No. 2:1-25. 